\title{
Isolation and Identification of New Acid-tolerant and Starch-degradable Yeasts
}

\author{
Viet Anh Thi Nguyen, Atsuko Tokuda, Takashi Mishima, Yoshio Nishida ${ }^{1}$ and Makoto Hisamatsu* \\ Laboratory of Food Science and Technology, Faculty of Bioresources, Mie University \\ (1515, Kamihama, Tsu 514-8507, Japan) \\ ${ }^{1}$ Food Research Institute, Aichi Prefecture Government (2-1-1, Shinpukuji-cho, Nishi-ku, Nagoya 451-0083, Japan)
}

\begin{abstract}
Two strains of acid-tolerant and starch-degradable yeast were isolated from rivers flowing in Kusatsu and Manza, considering an effective reuse of great mass of starch-based biodegradable plastic. The isolated strains could grow in acid media of pH 1.8 and were identified as Candida fluviatinis and Candida intermedia. The yeasts could assimilate many carbon sources and ferment glucose and sucrose in acid media to alcohol.
\end{abstract}

There is a growing interest in the development of degradable plastics to enhance biodegradability of plastic product in landfills and composts. ${ }^{1)}$ As a biodegradable plastic, polylactide or poly (lactic acid) (PLA) has become the focus of public attention. It is polymerized from lactic acid, which can be prepared effectively by fermentation with renewable resources such as starchy materials and cellulose. ${ }^{2,3)}$ But PLA is very expensive at present and a starch-based plastic blended from starch as main component and PLA as minor one is one of the most promising biodegradable polymers. ${ }^{4)}$

Research on the development of biodegradable polymers derived from renewable resources has gained considerable momentum in recent years. Together with research attending to production of new degradable polymers, it is also important to study the reuse of these polymers. ${ }^{5,6)}$ Until now, the studies have focused on PLA degradation through enzymatic ${ }^{2,7)}$ and acidic $^{8)}$ degradation. In the field of commercial biodegradable plastics, it seems that starch is used more than $50 \%$, and the utilization of the starch in the plastic after use should be also investigated. Although there are some studies concerning saccharification of starch $^{\text {) }}$ and cellulose ${ }^{10)}$ following alcohol fermentation by

\footnotetext{
${ }^{*}$ Corresponding author.
}

using Saccharomyces cerevisiae, it seems that there is room for improvement concerning economic policy.

In this paper, an isolation of acid-tolerant and starch-degradable yeasts was conducted in expectation of alcohol fermentation without sterilization.

\section{MATERIALS AND METHODS}

Isolation of acid-tolerant yeasts. The water samples $(25 \mathrm{~mL})$ collected from rivers flowing through areas of Kusatsu, and Manza hot springs were inoculated in $100 \mathrm{~mL}$ of acid medium $(\mathrm{pH}$ 2.5) using GPY medium containing 5\% glucose, $1 \%$ polypepton and $0.5 \%$ yeast extract, and carried out at $30^{\circ} \mathrm{C}$ for 5 days on a rotary shaker. Appropriately diluted cultures were spread on acid agar plates ( $\mathrm{pH} 2.5$ ) containing $1 \%$ glucose or $1 \%$ soluble starch, $0.5 \%$ yeast extract, $1.8 \%$ agar and penicillin $\mathrm{G}$ potassium (final $150 \mathrm{U} / \mathrm{mL}$ ) and incubated at $30^{\circ} \mathrm{C}$ for 5 days. Yeast-like colonies appearing were picked up from the plates and streaked on new plates. After cultivation, plates containing soluble starch were exposed to vapor of solid iodine by overturning the plates. Strains showing both a halo-like design around colonies on the starch plate and a comparatively large colony on the glucose plate were isolated and further 
purified three times by successive transference to acid GPY agar plates. Isolated strains growing on the acid GPY agar medium ( $\mathrm{pH} 2.5)$ were maintained at $4^{\circ} \mathrm{C}$.

Identification of yeast strains. Taxonomical characteristics of the isolated strains were investigated according to the methods described by N. J. W. Kreger-Van Rij, ${ }^{11)}$ and J. A. Barnett, R. W. Payne and D. Yarrow. ${ }^{12)}$ Morphologies of the vegetative cells of isolated strains were tested in YM medium ( $\mathrm{pH}$ 6.0) containing $1 \%$ glucose, $0.5 \%$ polypepton, $0.3 \%$ yeast extract and $0.3 \%$ malt extract.

Growth and fermentation conditions. The effect of $\mathrm{pH}$ on growth of isolated strains was studied in acid GPY medium by measuring the absorbance at $660 \mathrm{~nm}$. The $\mathrm{pH}$ of medium was adjusted with $4.5 \mathrm{M}$ and $1.0 \mathrm{M} \mathrm{H}_{2} \mathrm{SO}_{4}$ to $\mathrm{pH} \mathrm{3.0,2.5,} \mathrm{2.0,}$ 1.8 and 1.5 , respectively. ${ }^{13)} \mathrm{A}$ fermentation test was carried out by shaking at $150 \mathrm{rpm}$ at $30^{\circ} \mathrm{C}$ in 100 $\mathrm{mL}$ of acid GPY media. Effects on the carbon sources were also studied by replacing the glucose of the GPY medium with soluble starch (5\%), maltose $(5 \%)$, cellobiose $(1 \%)$, xylose $(1 \%)$, sucrose $(5 \%)$, or trehalose $(5 \%)$. Growth on the high concentrations of glucose and $\mathrm{Na}_{2} \mathrm{SO}_{4}$ were studied on the acid GPY media consisting of $10 \%$ and $20 \%$ glucose and $5 \% \quad \mathrm{Na}_{2} \mathrm{SO}_{4}$ respectively. Four brewing strains of $S$. cerevisiae (Kyokai No.3, Kyokai No.7, Kyokai No.9 and Shochu S2) were also tested in order to make a comparison with the isolated strains.

HPLC analysis of fermented alcohol. A culture was centrifuged at $5000 \mathrm{rpm}$ for $20 \mathrm{~min}$ and the supernatant $(20 \mu \mathrm{L})$ was analysed with a HPLC system (Tosoh Co., Ltd., Japan) with a refractive index detector, an analysis column (7.8 $\mathrm{mm}$ I.D $\times 30 \mathrm{~cm}$ ) of TSK gel Oapack-A (Tosoh Co., Ltd., Japan), and a guard column (6.0 mm I.D $\times 4 \mathrm{~cm})$ of TSK gel Oapack-P at room temperature using $0.75 \mathrm{mM} \mathrm{H}_{2} \mathrm{SO}_{4}$ as eluent at $0.6 \mathrm{~mL}$ / min.

\section{RESULTS AND DISCUSSION}

\section{Characterization of the isolated strains.}

From 120 acid-tolerant strains screened by using acid agar media, two strains were selected and designated as $2 \mathrm{C}$ and $3 \mathrm{~A}$, respectively. The acidtolerant abilities of $2 \mathrm{C}$ and $3 \mathrm{~A}$ strains were examined in the media with different initial $\mathrm{pH}$ value. Both strains grew well in acid media until pH 2.5 and could not grow in medium of $\mathrm{pH} 1.5$ (Fig. 1). Their starch-degradabilities were also checked on an acid agar-plate ( $\mathrm{pH} 2.5$ ) with $1 \%$ soluble starch (see Fig. 2). S. cerevisiae (Kyokai No.3, Kyokai No.7, Kyokai No.9 and Shochu S2) could grow in the acid medium but did not digest starch, while the two isolated strains could grow well and also
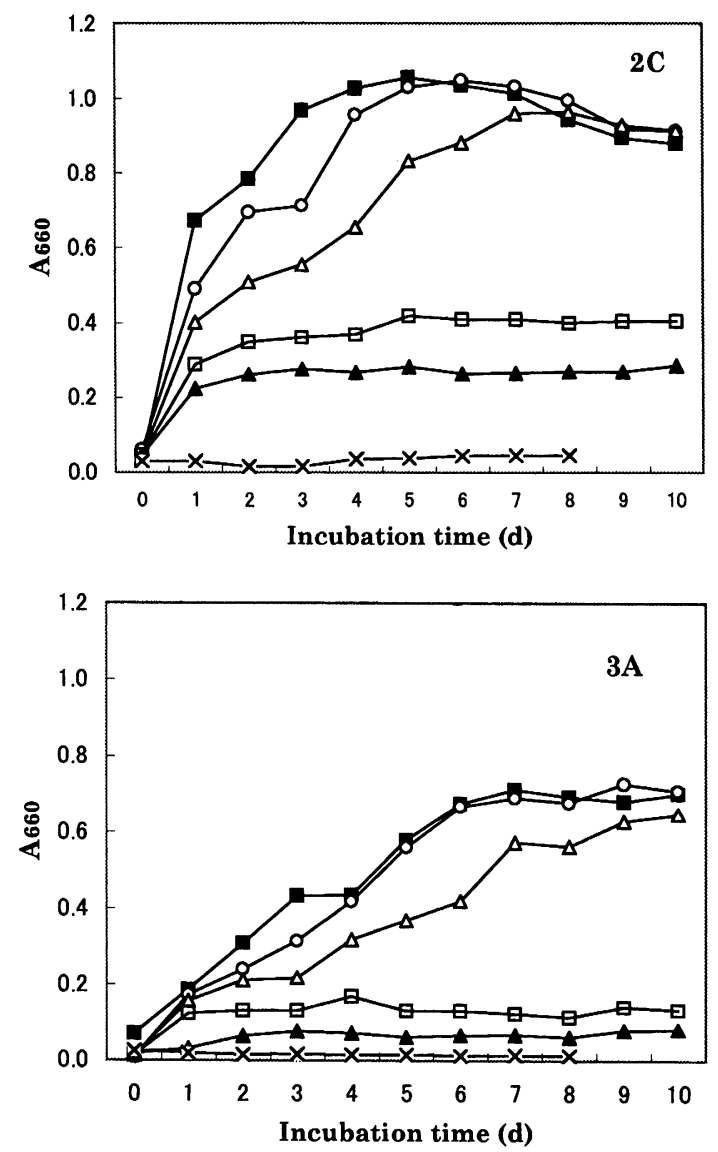

Fig. 1. Growth curves of $2 \mathrm{C}$ and $3 \mathrm{~A}$ strains in various acid media.

GPY media $(100 \mathrm{~mL})$ of $\mathrm{pH} 6.0$ and 3.0 were prepared by mixing with $0.07 \mathrm{~mL}$ and $1.1 \mathrm{~mL}$ of $1 \mathrm{M} \mathrm{H}_{2} \mathrm{SO}_{4}$, respectively, and those of $\mathrm{pH} 2.5,2.0,1.8$ and 1.5 were also prepared by mixing with $0.45,0.70,0.98$ and $1.1 \mathrm{~mL}$ of $4.5 \mathrm{M}$ $\mathrm{H}_{2} \mathrm{SO}_{4}$, respectively. The growth was followed by measuring the absorbance at $660 \mathrm{~nm}$. Symbols: $\square, \mathrm{pH} 6.0 ; \bigcirc, \mathrm{pH}$ $3.0 ; \triangle, \mathrm{pH} 2.5 ; \square, \mathrm{pH} 2.0 ; \Delta, \mathrm{pH} 1.8 ; \times, \mathrm{pH} 1.5$. 


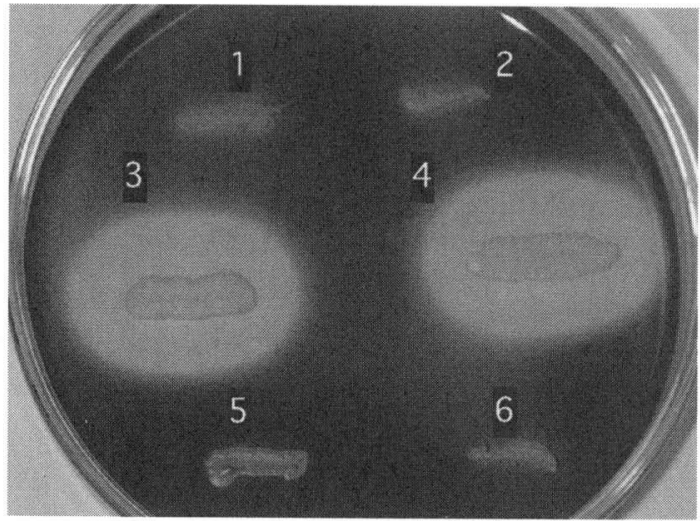

Fig. 2. Photograph of starch-degrading abilities.

1, S. cerevisiae No.3; 2, S. cerevisiae No.7; 3, strain 2C; 4, strain 3A; 5, S. cerevisiae No.9; 6, S. cerevisiae Shochu $2 S$. Plate overturned was exposed to vapor of solid for appropriate time.

showed a strong ability to digest starch in low $\mathrm{pH}$.

\section{Identification of the isolated strains.}

The physiological and biochemical characteristics of $2 \mathrm{C}$ and $3 \mathrm{~A}$ strains were investigated according to Kreger-Van $\mathrm{Rij}^{11)}$ and are summarized in
Table 1. Two strains showed abilities to ferment glucose, sucrose, maltose and trehalose and to assimilate many carbon compounds containing galactose, xylose, lactose, starch, cellobiose and some alditols. Assimilation of nitrogen compounds, the Diazonium Blue B (DBB) color test, urease test and starch formation were negative for boths strains.

There were some difference in characteristics between $2 \mathrm{C}$ and $3 \mathrm{~A}$. The growth of $2 \mathrm{C}$ strain in vitamin-free medium was positive, but that of $3 \mathrm{~A}$ strain was negative. The assimilations of rhamnose and raffinose were positive in $3 \mathrm{~A}$ strain and negative in $2 \mathrm{C}$ strain. Morphologies of their vegetative cells were different (see Fig. 3). Cells of 2C strain were round to short oval and those of $3 \mathrm{~A}$ strain were oval to ellipsoidal with multilateral budding.

According to the methods described in "The yeasts a taxonomic study," ${ }_{11}^{11}$ and "Yeasts: Characteristics and identification," ${ }^{12}$ it was suggested that strain $2 \mathrm{C}$ belong to Candida fluviatilis, and strain $3 \mathrm{~A}$ to Candida intermedia.

Table 1. Physiological and biochemical characteristics of $2 \mathrm{C}$ and $3 \mathrm{~A}$ strains.

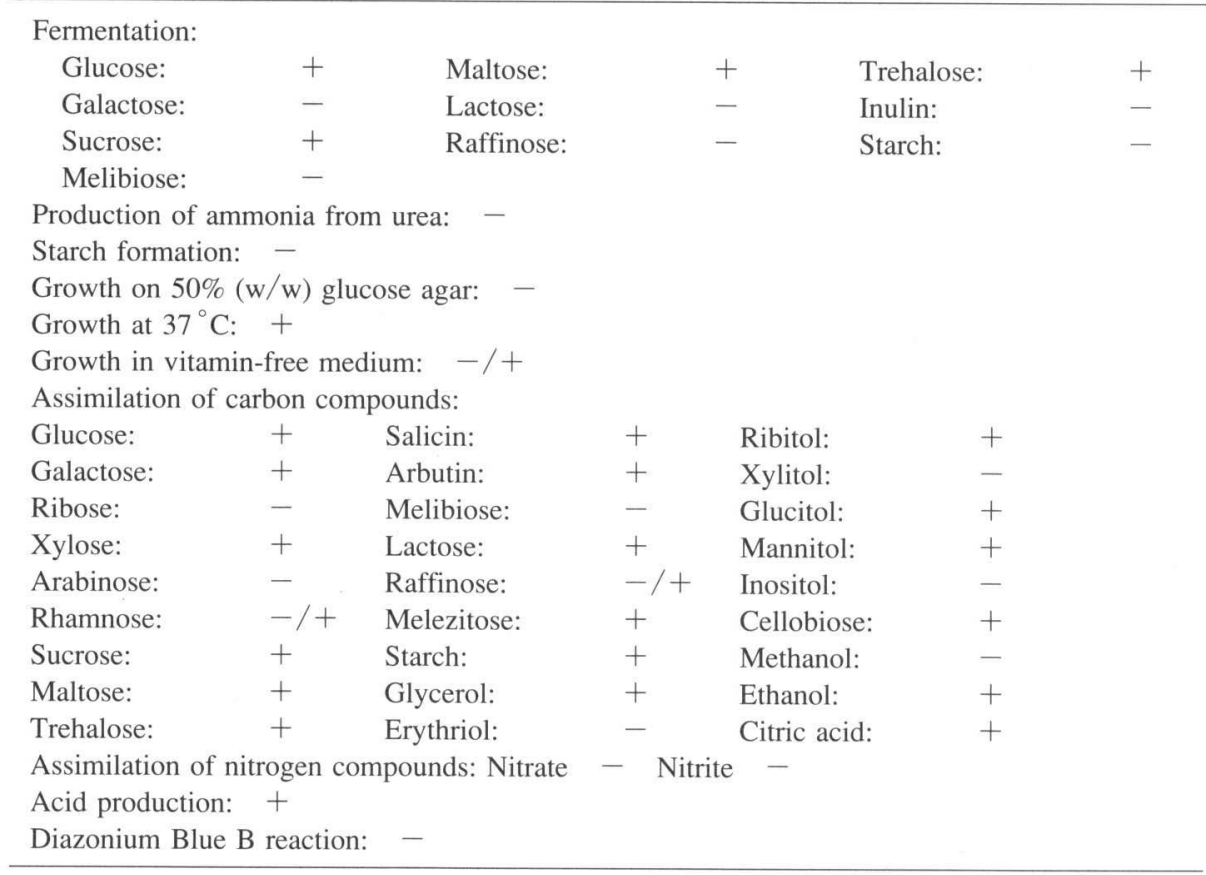

Items indicating different contents between $2 \mathrm{C}$ and $3 \mathrm{~A}$ shown by separation with slash: result of $2 \mathrm{C}$ is left side and that of $3 \mathrm{~A}$ is right side. 


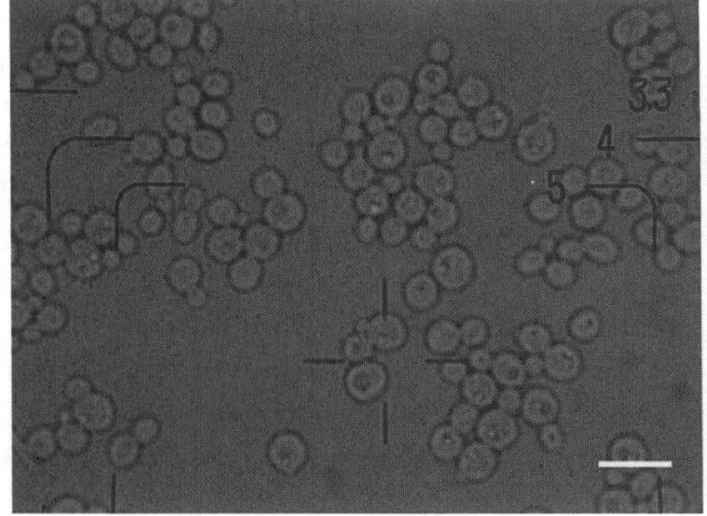

(A)

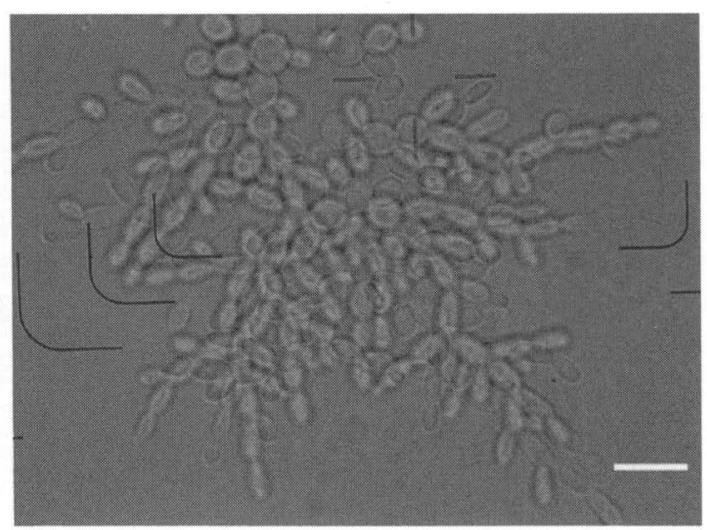

(B)

Fig. 3. Morphologies of vegetative cells of strains of $2 \mathrm{C}(\mathrm{A})$ and $3 \mathrm{~A}(\mathrm{~B})$.

Vegetative cells growing in YM medium ( $\mathrm{pH} \mathrm{6.0)}$ ) for 3 days at $30^{\circ} \mathrm{C}$ were observed by microscopy. Bar scale: $10 \mu \mathrm{m}$.

\section{Effects of substrates on growth and alcohol fermentation.}

The fermentation test shown in Table 1 was indicated by the production of carbon dioxide from carbohydrates because of taxonomical analysis. So, definite alcohol production needed to be ascertained, and $C$. fluviatilis $2 \mathrm{C}$ and $C$. intermedia $3 \mathrm{~A}$ were therefore cultivated in $100 \mathrm{~mL}$ of acid GPY media ( $\mathrm{pH} 2.5$ ) with soluble starch, maltose, cellobiose, xylose, sucrose, glucose and trehalose, respectively. Some properties of cultures containing alcohol fermentation are shown in Table 2. It was found that only glucose and sucrose were the sub- strates for ethanol production and their final $\mathrm{pH}$ values did not change, but cultures of other carbon substrates were considered as non alcoholfermentation and their $\mathrm{pH}$ values rose.

\section{Growth on high concentrations of glucose and $\mathrm{Na}_{2} \mathrm{SO}_{4}$}

For unsterilized alcohol-fermentation of acid hydrolysate derived from starch-based biodegradable plastic, it should be verified that isolated strains can grow and ferment alcohol in acid media containing high concentrations of sugar because the high concentration of substrate is normally inhibitory to fermentation. ${ }^{14)}$ The effect of salt resulting

Table 2. Growth and fermentation of $C$. fluviatinis $2 \mathrm{C}$ and $C$. intemedia $3 \mathrm{~A}$ for various substrates in acid GPY media of $\mathrm{pH} 2.5$.

\begin{tabular}{|c|c|c|c|c|c|c|}
\hline \multirow{2}{*}{$\begin{array}{c}\text { Carbon source } \\
(\%)^{b}\end{array}$} & \multicolumn{2}{|c|}{$\mathrm{OD}^{a}$ at $660 \mathrm{~nm}$} & \multicolumn{2}{|c|}{ Final $\mathrm{pH}$ of cultures } & \multicolumn{2}{|c|}{ Alcohol fermentation ${ }^{c}$} \\
\hline & $2 \mathrm{C}$ & $3 \mathrm{~A}$ & $2 \mathrm{C}$ & $3 \mathrm{~A}$ & $2 \mathrm{C}$ & $3 \mathrm{~A}$ \\
\hline None & 0.45 & 0.32 & 7.0 & 7.3 & - & - \\
\hline Soluble starch (5) & 0.88 & 0.74 & 3.9 & 3.5 & - & - \\
\hline Maltose (5) & 1.12 & 0.69 & 2.6 & 3.2 & - & - \\
\hline Cellobiose (1) & 0.97 & 0.54 & 5.6 & 6.2 & - & - \\
\hline Xylose (1) & 0.82 & 0.46 & 2.9 & 3.5 & - & - \\
\hline Sucrose (5) & 1.05 & 0.73 & 2.4 & 2.5 & + & + \\
\hline Glucose (5) & 1.06 & 0.67 & 2.3 & 2.4 & + & + \\
\hline Trehalose (5) & 0.93 & 0.56 & 3.4 & 3.3 & - & - \\
\hline
\end{tabular}

${ }^{a}$ Absorbance at $660 \mathrm{~nm}$ of culture grown in $100 \mathrm{~mL}$ of acid GPY medium in $300 \mathrm{~mL}$ flask at $30^{\circ} \mathrm{C}$ for 5 days. ${ }^{b}$ The number in parentheses indicate the percentages of subsrate. ${ }^{c}$ Alcohol fermentation was decided by checking a peak of ethanol by HPLC. 
from the neutralization of the acid hydrolysate of starch should be also considered. Our tentative hydrolysis conditions showing good yield of reducing sugar from $50 \%(\mathrm{w} / \mathrm{v})$ corn starch were $0.4 \mathrm{M}$ $\mathrm{H}_{2} \mathrm{SO}_{4}$ at $110^{\circ} \mathrm{C}$ and the concentration of sulfate after neutralization was estimated to be about $5 \%(\mathrm{w} / \mathrm{v})$. So, effects of high concentrations of glucose and/or $\mathrm{Na}_{2} \mathrm{SO}_{4}$ on the growth of $C$. fluviatilis $2 \mathrm{C}$ and $C$. intermedia $3 \mathrm{~A}$ were tested, and some strains of $S$. cerevisiae were also tested for comparison. All strains tested could grow well in $\mathrm{pH} 2.5$ media with 10 and $20 \%$ glucose. Four strains of $S$. cerevisiae could not grow in $\mathrm{pH} 2.5$ medium with $10 \%$ glucose and $5 \% \quad \mathrm{Na}_{2} \mathrm{SO}_{4}$. The growths of strains $2 \mathrm{C}$ and $3 \mathrm{~A}$ measuring by optical density at $A_{660}$ showed more than 0.5 , it was indicated that they were the salt-tolerant yeasts.

\section{Ethanol production under unsterile condition.}

Ethanol fermentation of $2 \mathrm{C}$ and $3 \mathrm{~A}$ strains was investigated without sterilization in GPY medium of $\mathrm{pH} 2.5$ containing $10 \%$ glucose and $5 \% \mathrm{Na}_{2} \mathrm{SO}_{4}$. Although these acid-tolerant yeasts grow well in these acid conditions, their alcohol productions were very low (about 1\%) and the yield was far from the value expected. However, it was expected that there is potential for developing a technology for a bio-conversion system producing fuel ethanol from starch-based biodegradable plastic.

\section{REFERENCES}

1 ) J.C. Huang, A.S. Shetty and M.S. Wang: Biodegradable plastics: A review. Adv. Polym. Technol., 10, 23-30 (1990).

2 ) H. Pranamuda, Y. Tokiwa and H. Tanaka: Polylactide degradation by an Amycolatopsis sp. Appl. Environ. Microbiol., 63, 1637-1640 (1997).

3 ) P. Yin, N. Nishina, Y. Kosakai, K. Yahiro, Y. Park and M. Okabe: Enhanced production of $\mathrm{L}(+)$-lactic acid from corn starch in a culture of Rhizopus oryzae using an air-lift bioreactor. J. Ferment. Bioeng., 84, 249-253 (1997).

4 ) S. Bhatnagar and M.A. Hanna: Starch-based plastic foams from various starch sources. Cereal Chem., 73, 601-604 (1996).

5 ) R. Chinnaswamy and M.A. Hanna: Extrusion-grafting starch onto vinylic polymers. Starch/Stärke, 43, 396402 (1991).

6 ) I. Cacciari, P. Quatrini, G. Zirletta, E. Mincione, V.
Vinciguerra, P. Lupattelli and G.G. Sermanni: Isotactic polypropylene biodegradation by a microbial community: Physicochemical characterization of metabolites produced. Appl. Environ. Microbiol., 59, 36953700 (1993).

7 ) A.L. Pometto, III, B. Lee and K.E. Johnson: Production of an extracellular polyethylene-degrading enzyme(s) by Streptomyces species. Appl. Environ. Microbiol., 58, 731-733 (1992).

8 ) M. Vert, A. Torres, S.M. Li, S. Roussob and. H. Garreau: The complexity of the biodegradation of poly (2hydroxy acid)-type aliphatic polyesters. in Biodegradable Plastics and Polymers, Y. Doi and K. Fukuda, eds., Elsevier Science, Amsterdam, pp. 11-23 (1994).

9 ) F. Kobayashi, T. Sawada, Y. Nakamura, M. Ohnaga, M. Godliving and T. Ushiyama: Saccharification and alcohol fermentation in starch solution of stemexploded potato. Appl. Biochem. Biotechnol., 69, 177189 (1998).

10) P. Chandrakant and V.S. Bisaria: Simultaneous bioconversion of cellulose and hemicellulose to ethanol. Crit. Rev. Biotechnol., 18, 295-331 (1998).

11) N.J.W. Kreger-Van Rij: The Yeast: A Taxonomic Study, Elsevier Science Publishers, B. V., Amsterdam (1984).

12) J.A. Barnett, R.W. Payne and D. Yarrow: Yeast: Characteristics and Identification, Cambridge University Press, Cambridge (2000).

13) V.A.T. Nguyen, K. Senoo, T. Mishima and M. Hisamatsu: Multiple tolerance of Rhodotorula glutinis R-1 to acid, aluminum ion and manganese ion, and its unusual ability of neutralizing acidic medium. $J$. Biosci. Bioeng., 92, 366-371 (2001).

14) R.P. Jones, N. Pamment and P.F. Greenfield: Alcohol fermentation by yeasts - the effect of environmental and other variables. Process Biochem., April/May, 4249 (1981).

(Received October 9, 2001; Accepted December 10, 2001)

新規酸性耐性および澱粉分解性酵母の分離同定

$$
\begin{gathered}
\text { ウェト アン ティ グエン, 徳田濃子 } \\
\text { 三島 隆, 西田淑男 }{ }^{1}, \text { 久松 眞 } \\
\text { 三重大学生物資源学部食品資源工学研究室 } \\
\text { (514-8507 津市上浜町 1515) } \\
\text { 1 愛知県食品工業センター } \\
\text { (451-0083 名古屋市西区新福寺町 2-1-1) }
\end{gathered}
$$

澱粉を主体とする大量な生分解プラスチックの再資 源化を考慮に入れて，二株の酸性耐性および澱粉分解 性酵母を草津および万座を流れる河川から単離した。 単離した株は pH 1.8 の酸性培地で生育でき, Candida fluviatinis and Candida intermedia と同定された。この 酵母は，多くの炭素源を資化でき，さらにグルコース と砂糖からアルコールを発酵することができた。 